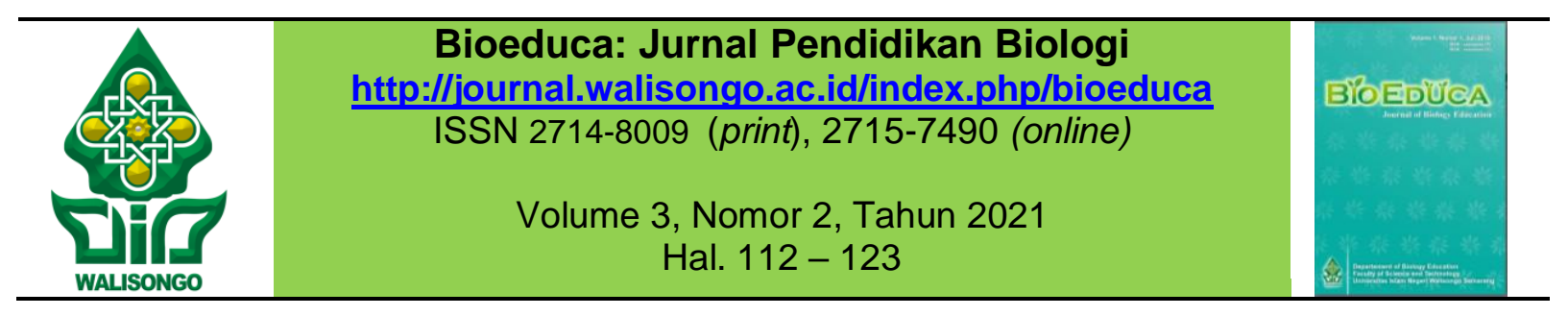

\title{
Pengembangan Media Pembelajaran Berbasis Android pada Materi Sistem Imunitas
}

\author{
Tuti Alawiyah ${ }^{1^{*}}$, Muhammad Muttaqien ${ }^{2}$, Hadiansah ${ }^{3}$ \\ 1,2,3 Pendidikan Biologi, Universitas Islam Negeri Sunan Gunung Djati Bandung \\ "Email: alawiyahtuti2498@gmail.com
}

\begin{tabular}{|c|c|}
\hline Informasi Artikel & ABSTRAK \\
\hline $\begin{array}{l}\text { Submit: } 19-10-2020 \\
\text { Diterima: } 15-09-2021 \\
\text { Dipublikasikan: } 15-09-2021\end{array}$ & $\begin{array}{l}\text { Penelitian ini bertujuan untuk mengetahui kelayakan media } \\
\text { pembelajaran, dan untuk mendeskripsikan respon siswa } \\
\text { terhadap media pembelajaran berbasis android pada materi } \\
\text { sistem imunitas. Metode penelitian yang digunakan adalah } \\
\text { metode penelitian dan pengembangan dengan tahapan } \\
\text { pengembangan 3D (Define, Design, dan Development). } \\
\text { Penelitian dilaksanakan di SMAN } 1 \text { Palabuhanratu pada peserta } \\
\text { didik kelas XI MIPA yang berjumlah } 15 \text { peserta didik. Instrumen } \\
\text { yang digunakan adalah lembar validasi media pembelajaran. } \\
\text { Teknik analisis data yang digunakan adalah analisis data } \\
\text { kualitatif yaitu validasi media pembelajaran dan teknik data } \\
\text { analisis respon angket siswa terhadap media pembelajaran } \\
\text { dengan menggunakan skala pengukuran rating scale. Indikator } \\
\text { penilaian media oleh ahli materi meliputi kurikulum, penyajian } \\
\text { materi, penggunaan Bahasa dan evaluasi, dan indikator oleh ahli } \\
\text { media meliputi desain tampilan, aksesbilitas, penggunaan } \\
\text { Bahasa dan keterlaksanaan. Hasil uji validasi media } \\
\text { pembelajaran oleh ahli media dan ahli materi memperoleh } \\
\text { persentase sebesar } 79,90 \% \text { dengan kriteria valid dan layak dan } \\
81,84 \% \text { dengan kriteria valid dan sangat layak, dan respon siswa } \\
\text { terhadap penggunaan media pembelajaran memperoleh hasil } \\
\text { sebesar 79,65\% dengan kriteria valid dan baik. } \\
\text { Kata kunci: android; media pembelajaran; sistem imunitas. }\end{array}$ \\
\hline Penerbit & ABSTRACT \\
\hline $\begin{array}{l}\text { Program Studi Pendidikan } \\
\text { Biologi, Fakultas Sains dan } \\
\text { Teknologi, UIN Walisongo } \\
\text { Semarang }\end{array}$ & $\begin{array}{l}\text { This study aims to determine the feasibility of learning media, } \\
\text { and to describe students' responses to Android-based learning } \\
\text { media on the immunity system material. The research method } \\
\text { used is the method of research and development with } 3 D \\
\text { development stages (Define, Design, and Development). The } \\
\text { research was conducted at SMAN } 1 \text { Palabuhanratu in class XI } \\
\text { MIPA students, amounting to } 15 \text { students. The instrument used } \\
\text { was the learning media validation sheet. The data analysis } \\
\text { technique used was the validation data analysis of the learning } \\
\text { media and the data analysis techniques of the student's } \\
\text { questionnaire response to the learning media using the rating } \\
\text { scale measurement scale. Indicators of media assessment by } \\
\text { material experts include curriculum, material presentation, use of } \\
\text { language and evaluation, and indicators by media experts } \\
\text { include display design, accessibility, language use and } \\
\text { implementation. The results of the validation test of learning } \\
\text { media by media experts and material experts obtained a } \\
\text { percentage of } 79,90 \% \text { with valid and feasible criteria and } 81.84 \% \\
\text { with valid and very feasible criteria, and student responses to the }\end{array}$ \\
\hline
\end{tabular}


use of learning media obtained results of $79.65 \%$ with valid and good criteria.

Keywords: android; learning media; immunity system.

Copyright C2021, Bioeduca: Journal of Biology Education

\section{PENDAHULUAN}

Pendidikan merupakan tindakan yang dilaksanakan manusia secara sengaja dan secara sadar yang mana tujuannya agar perilaku manusia menjadi baik secara perorangan atau kelompok, dengan tujuan mendewasakan manusia melalui pelatihan dan pengajaran (Sugiharto, 2007:5). Dalam pendidikan ada yang dinamakan proses belajar, dengan belajar manusia dapat mengubah dirinya kearah yang lebih baik. Menurut Gagne (2006:2) peristiwa berubahnya manusia pada awalnya belum memiliki kemampuan atau keahlian menjadi memiliki keahlian atau kemampuan tersebut, hal itu dikarenakan manusia tersebut telah melakukan proses belajar.

Manusia untuk memperoleh berbagai macam kompetensi, kecakapan, dan perilaku dapat diperoleh dengan cara belajar. Perbedaan manusia dengan makhluk hidup lain adalah manusia memiliki karakteristik yang penting yaitu kemampuan belajar. Keuntungan belajar tidak hanya didapatkan bagi hanya individu itu sendiri tapi bagi masyarakat juga, yakni belajar mempunyai peranan penting dalam transfer budaya dari generasi ke generasi sedangkan bagi individu itu sendiri keuntungan belajar tentunya memberikan kontribusi untuk pengembangan kualitas hidupnya (Baharudin dan Wahyuni, 2012:11-12).

Bagian terpenting dalam proses pendidikan adalah adanya proses belajar mengajar yang mana di dalamnya terdapat interaksi peserta didik sebagai pendidik dan murid yang sedang belajar. Usman (2001:4) mengatakan cara yang terdapat serangkaian atau berbagai aktivitas pendidik dan peserta didik karena interaksi yang berlangsung melalui hubungan pendidikan agar berhasil mendapatkan maksud tertentu adalah bagian dari serangkaian belajar mengajar. Sedangkan menurut Sukewi (1994:19) ada komponen yang saling berhubungan pada proses belajar mengajar yaitu guru, siswa, bahan ajar, tujuan pengajaran, metode pengajaran dan media pembelajaran.

Proses pembelajaran untuk meraih hasil belajar yang maksimal yaitu harus ada korelasi antar faktor yang saling melengkapi. Faktor tersebut diantaranya adalah media pembelajaran, yang mana media pembelajaran ini menjadi salah satu faktor yang penting diantara faktor yang lainnya dalam pembelajaran. Selain untuk meningkatkan keinginan dan semangat peserta didik, media juga bisa menjadi perangsang peseta didik untuk meningkatkan penguasaan konsep pembelajaran dalam kegiatan pembelajaran. Proses pendidikan menjadi lebih efektif, efesien, bermakna dan cepat itulah harapan ketika pembelajaran menggunakan media (Musfiqon, 2012: 178-179).

Kehidupan ini kita tidak bisa menghindari kemajuan teknologi yang semakin hari semakin sangat cepat dan pesat. Kemajuan tersebut dapat dirasakan di seluruh bidang, salah satu nya dapat dirasakan dibidang pendidikan yang mana saat ini 
mengalami perubahan yang sangat besar. Kini siswa dapat mengakses sumber ilmu pengetahuan secara luas dan bebas tanpa ada yang membatasinya seperti waktu dan tempat dan tidak harus ada guru yang mendampingi, dengan bantuan internet dan media elektronik, guru sekarang ini sudah tidak menjadi satu-satunya sumber illmu pengetahuan bagi siswa (Riswandi,2013:95).

Salah satu teknologi yang kini berkembang dalam bidang pendidikan adalah $\mathrm{m}$ learning (mobile learning). Konsep mobile learning ini menggunakan perangkat mobile yang dianggap memudahkan siswa untuk membawanya kapanpun, dimanapun, kemanapun dan dianggap fleksibel ketika digunakan siswa sebagai media pembelajaran (Ibrahim dan ishartiwi, 2017:81). Mobile learning ini salah satu yang dapat mengatasi permasalahan dalam sistem pembelajaran tradisional dan dapat meningkatkan sistem pembelajaran secara keseluruhan (Irwanto, 2017:78). Contoh perangkat mobile yang dapat digunakan pada mobile learning yaitu smartphone, laptop, tablet PC dan PDA.

Berdasarkan hasil studi pendahuluan disalah satu SMAN Kabupaten Sukabumi penggunaan medianya sudah cukup variatif yaitu menggunakan LKS, papan tulis, proyektor dengan jumlah yang terbatas, smart board, dan menggunakan smartphone. Walaupun media pembelajaran yang digunakan sudah cukup variatif namun media pembelajaran yang dominan digunakan yaitu papan tulis dan LKS, dengan metode ceramah sehingga membuat peserta didik merasa jenuh dan bosan. Kendala lainnya adalah kesulitan peserta didik pada materi-materi biologi yang dianggap terlalu abstrak oleh peserta didik yaitu materi sistem imunitas. Hal tersebut menjadikan siswa memiliki hasil belajar yang rendah, khususnya pada materi sistem imunitas mencapai $66 \%$ dari 38 siswa yang tidak dapat mencapai nilai Kriteria Ketuntasan Minimal (KKM).

Cimer (2012:61-71) mengatakan materi biologi yang paling sulit dipelajari ada lima yaitu sistem endokrin dan hormon, respirasi aerob, definisi sel, sistem imun, dan tentang siklus. Kesulitan materi sistem imunitas ada diurutan kelima tersukar dengan sampel penelitian sebanyak 39 siswa. Biologi mencakup banyak konsep, beberapa konsep terlalu abstrak, beberapa materi tidak bisa dilihat langsung atau tidak dapat dilihat oleh mata telanjang, dan terdapat banyak Bahasa latin itulah beberapa faktor penyebab yang menjadikan sulit.

Melihat fakta yang ada di lapangan bagaimana kesulitan siswa terhadap materi sistem imun maka diperlukannya suatu media yang dapat mengirimkan informasi yang abstrak secara efesien, efektif dan benar. Menggunakan berbagai media memberikan peluang agar dapat mengirimkan ilmu secara maksimal. Menurut Hackbarth (1996:85-86) multimedia merupakan beberapa media yang penggunaannya gabungan dari berbagai media dalam menyampaikan informasi, baik berupa animasi grafis atau grafis, video, informasi audio, dan teks.

Observasi secara langsung siswa kelas XI MIA sekitar $84 \%$ atau 32 peserta didik dari 38 peserta didik merupakan pengguna smartphone dengan sistem operasional android, sedangkan sisanya menggunakan smartphone dengan sistem operasional lain, hal ini sebagai peluang untuk guru agar memanfaatkan smartphone android 
tersebut sebagai media pembelajaran. Berdasarkan hasil studi pendahuluan yang telah dipaparkan diatas maka peneliti tertarik untuk melakukan penelitian Pengembangan Media Pembelajaran Berbasis Android pada Materi Sistem Imunitas.

Media pembelajaran berbasis android dapat menarik minat siswa untuk belajar, sesuai dengan Putra dkk (2017: 2013) pemilihan media pembelajaran berbasis teknologi yaitu smartphone dapat memberikan ketertarikan sendiri bagi siswa dan membuat siswa dapat mengakses materi dalam aplikasi dimana saja dan kapan saja. Hal tersebut memungkinkan dapat meningkatkan minat dan hasil belajar siswa.

\section{METODE PENELITIAN}

Jenis penelitian yang dilakukan adalah Research and Development (R\&D). metode ini nantinya akan menghasilkan suatu produk dan yang dihasilkannya adalah media pembelajaran berbasis android pada materi sistem imunitas, metode ini digunakan untuk menghasilkan produk dan menguji validitas produk tersebut (Sugiyono, 2013:407). Model yang digunakan adalah model 4-D yang dikemukakan oleh Thiagaradjan (1974) dalam Trianto (2013:189) yaitu model pengembangan 4D Model yang terdiri dari empat tahap pengembangan yaitu define, design, develop dan desseminate atau sekarang diadaptasikan menjadi 4-P, yaitu pendefinisian, perancangan, pengembangan dan penyebaran (Trianto, 2009:179-192).

Penelitian ini dibatasi sampai tahap 3D karena keterbatasan waktu, biaya (Elvarita, 2020:6) dan saat penelitian dilakukan sedang terjadinya wabah pandemi COVID 19. Langkah-langkah pengembangan yang dilakukan yaitu terdari dari tiga tahap, tahap tersebut adalah Define, Design, dan Development yaitu hanya sampai pada tahap pengembangan. Alasan dibatasi menjadi 3-D didasari pada model pengembangan yang disederhanakan menjadi studi pendahuluan, pengembangan model, dan pengujian model, karena penelitian ini disebar secara terbatas dan tidak disebar secara luas (Sukmadinata, 2017:187).

Produk yang telah dikembangkan selanjutnya di uji skala kecil dengan subjek 15 orang siswa dikelas XI MIA. Teknik analisis data kualitatif yang digunakan adalah analisis Data Validasi Media Pembelajaran berbasis Android, dan Analisis Angket Respon Siswa terhadap Media Pembelajaran berbasis Android.

Uji validitas produk media pembelajaran berbasis android dilakukan oleh ahli materi sistem imunitas dan ahli media pembelajaran. Uji validitas maupun dilakukan dengan skala pengukuran rating scale. kriteria penilaian uji validasinya terdiri dari lima tingkatan disajikan dalam tabel pada Tabel 1 yaitu sebagai berikut:

Tabel 1 Ketentuan Pemberian Skor

\begin{tabular}{|c|c|c|c|}
\hline \multirow{2}{*}{ Penilaian } & \multirow{2}{*}{ Keterangan } & \multicolumn{2}{|c|}{ Pernyataan } \\
\cline { 3 - 4 } & & + & - \\
\hline 1 & Sangat Tidak Layak & 1 & 5 \\
\hline 2 & Tidak Layak & 2 & 4 \\
\hline 3 & Cukup & 3 & 3 \\
\hline 4 & Layak & 4 & 2 \\
\hline 5 & Sangat Layak & 5 & 1 \\
\hline
\end{tabular}

(Sumber: Riduwan dan Akdon, 2013:16) 
Data yang terkumpul dihitung skor rata-rata setiap kriteria yang dinilai dengan rumus (Arikunto, 2005:284):

$x=\frac{\sum \bar{X}}{N}$

Keterangan:

$\bar{X}=$ Rata-rata nilai

$\Sigma X=$ Jumlah nilai mentah yang dimiliki subjek

$N=$ Banyaknya subjek yang memiliki nilai

Melihat kelayakan media pembelajaran dari hasil data penilaian para ahli digunakan skala pengukuran rating scale. Menurut Ridwan dan Akdon (2013:23). Rating scale yaitu data mentah yang diperoleh berupa angka, kemudian ditafsirkan ke dalam pengertian kualitatif. Menghitung persentase perolehan skor dan menentukan kisaran kriteria persentase dengan rumus:

$$
P=\frac{\text { Jumlah Skor yang diperoleh }}{\text { Jumlah Skor Kriterium }} \times 100 \%
$$

Kriteria Penilaian

$\begin{array}{ll}\text { Skor tertinggi } & =5 \\ \text { Skor terendah } & =1 \\ \text { Jumlah kelas } & =5\end{array}$

Mencari rentang kelas, dengan rumus (Usman dan akbar, 2008:71):

Maka, $\mathrm{R}=5-1=4$

data tertinggi - data terendah

Kemudian menghitung panjang interval dengan rumus (Usman dan akbar, 2008:71):

$$
P=\frac{\text { rentang }}{\text { banyak kelas }}=\frac{4}{5}=0,80
$$

Sehingga tabel kriteria kualitas media dapat dilihat pada Tabel 1 dan range persentase dan kriteria kualitas media dapat dilihat pada Tabel 2 sebagai berikut berikut:

Tabel 2 Range dan Kriteria Kualitas Media

\begin{tabular}{|c|c|}
\hline Skor & Kriteria \\
\hline $4,20-5,00$ & Sangat layak \\
\hline $3,40-4.19$ & Layak \\
\hline $2,60-3,39$ & Cukup Layak \\
\hline $1,80-2,59$ & Kurang Layak \\
\hline $1,00-1,79$ & Tidak Layak \\
\hline
\end{tabular}

(Sumber: Usman dan akbar, 2008:71)

Untuk menentukan kisaran dan kriteria persentase, digunakan rumus :

$$
\operatorname{Interval}(i)=\frac{100}{\text { Jumlah Kriteria }}
$$




\section{Tabel 3 Range Persentase dan Kriteria Kualitas Media}

\begin{tabular}{|c|c|}
\hline Skor & Kriteria \\
\hline $81 \%-100 \%$ & Sangat layak \\
\hline $61 \%-80 \%$ & Layak \\
\hline $41 \%-60 \%$ & Cukup Layak \\
\hline $21 \%-40 \%$ & Kurang Layak \\
\hline$\leq 20 \%$ & Tidak Layak \\
\hline
\end{tabular}

(Sumber: Riduwan dan Akdon, 2013:16)

Analisis Angket respon peserta didik sama dengan analisis Data Validasi Media Pembelajaran berbasis Android yaiti menggunakan skala bertingkat (rating scale). Angket atau kuesioner ialah salah satu teknik pengumpulan data yang dilakukan tanpa adanya proses tanya jawab langsung antara peneliti dengan responden. Adapun alat atau instrumen yang digunakan ialah angket yang berisi sejumlah pertanyaan atau pun pernyataan yang harus dijawab responden (Sukmadinata, 2012: 219). Penggunaan angket dilakukan untuk mengetahui respon siswa terhadap penggunaan media pembelajaran berbasis android dengan pada materi Sistem Imunitas.

\section{HASIL PENELITIAN DAN PEMBAHASAN}

Penelitian dan pengembangan ini hasilnya adalah sebuah media pembelajaran berbasis android yang berisi materi Sistem Imunitas. Media pembelajaran berbasis android disusun dengan mengacu pada kebutuhan pembelajaran yang dianalisis melalui studi pendahuluan, disesuaikan dengan kurikulum yang digunakan melalui analisis $\mathrm{KI}, \mathrm{KD}$, penentuan tujuan pembelajaran dan juga indikator pencapaian kompetensi (IPK), kemudian media pembelajaran berbasis android ini didalamnya dilengkapi soal evaluasi untuk mengukur kognitif peserta didik pada materi sistem imunitas.

Media pembelajaran berbasis android adalah salah satu media yang memanfaatkan sistem informatika yang mana dalam proses pembuatannya menggunakan aplikasi-aplikasi perangkat software yang terdapat dalam PC atau laptop yaitu Android Studio dan aplikasi pendukung lainnya. Adapun skema karakertistik pada media berbasis android pada materi sistem imunitas yang dihasilkan dapat dilihat pada Gambar 1.

Media pembelajaran berbasis android pada materi sistem imunitas yang berbentuk aplikasi dapat diunduh di google playstore dengan ukuran kapasitas $8,7 \mathrm{MB}$, terdapat tiga menu samping didalam aplikasi tersebut yaitu home yang mana berisi menu-menu yang dapat diakses yaitu standar kompetensi, pendahuluan, video pembelajaran, materi dalam materi ini terdapat menu-menu yang dapat diakses lagi berupa sub-sub materi, dan evaluasi. Menu samping yang kedua yaitu referensi dan menu samping ketiga yaitu profil. 


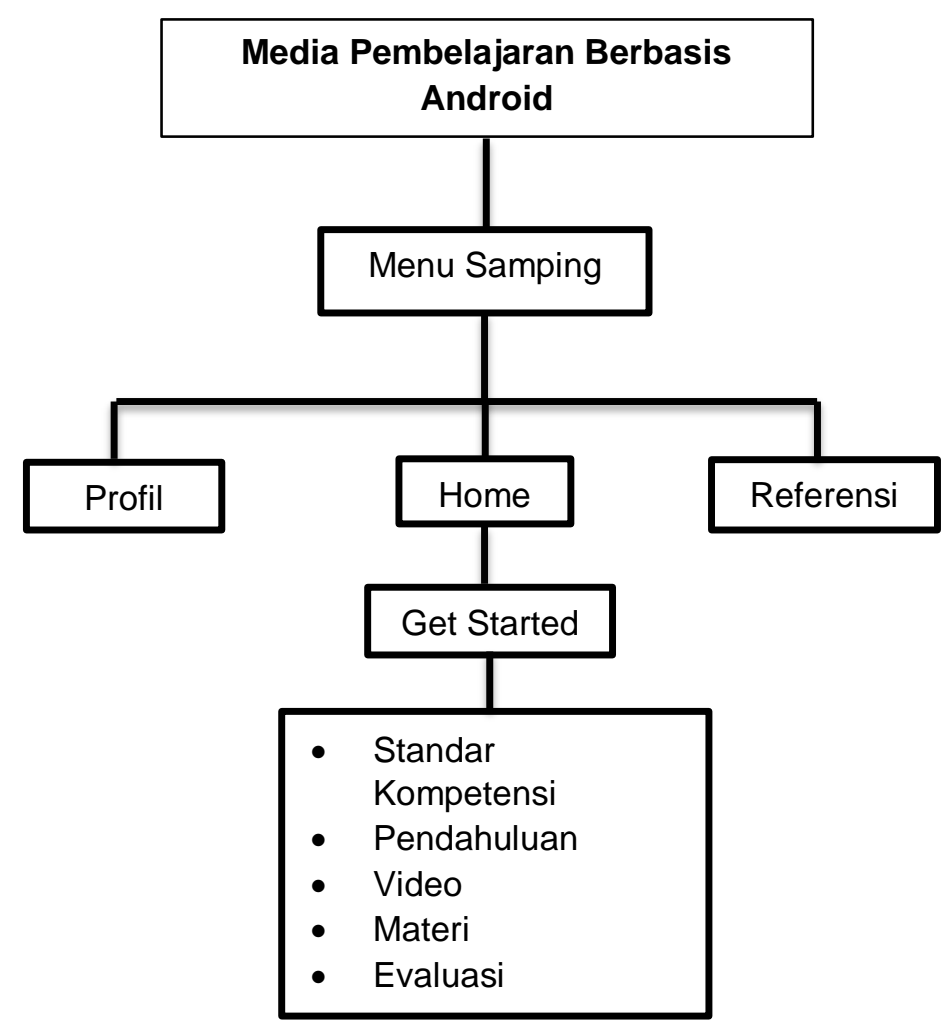

Gambar 4.1 Skema Media pembelajaran

Proses pengembangan media pembelajaran dilakukan melalui proses pembuatan proposisi yang kemudian dikembangkan ke dalam bentuk struktur makro dan mikro untuk dibuat ke dalam bentuk media pembelajaran berbasis android. Mengacu pada rumusan-rumusan masalah, maka hasil penelitian ini meliputi hasil uji validasi oleh ahli materi, ahli media, dan guru, dan juga respon siswa terhadap media pembelajaran berbasis android pada materi Sistem Imunitas. Adapun data hasil penelitian dan pengembangan ialah sebagai berikut:

Tahapan Pengembangan Media Pembelajaran berbasis Android pada materi Sistem Imunitas. Proses pengembangan Media Pembelajaran berbasis Android dengan aplikasi EdBiold dilakukan melalui tahapan pengembangan 4-D yang dilakukan oleh Thiagarajan (1974). Tahapan dalam penelitian dan pengembangan ini dilakukan dari define, design, development sampai pada tahap develop. Namun, tahapan dari pengembangan media pembelajaran berbasis android pada materi Sistem Imunitas secara lengkap akan dijelaskan di bawah ini:

a. Define (Pendefinisian)

Tahapan ini mengidentifikasi masalah yang menjadi latarbelakang kebutuhan akan pengembangan media pembelajaran berbasis android pada materi Sistem Imunitas melalui studi pendahuluan di salah satu sekolah SMAN Kabupaten Sukabumi, yaitu proses wawancara bersama guru pengampu mata pelajaran biologi.

Adapun analisis tugas dilakukan dengan menganalisis silabus yang digunakan oleh sekolah untuk menentukan batasan materi, menentukan indikator pencapaian kompetensi (IPK) dan tujuan pembelajaran sehingga sesuai dengan kompetensi

\section{8 \\ Alawiyah et al. - Pengembangan Media Pembelajaran Berbasis Android pada} Materi Sistem Imunitas 
dasar (KD) dan Kompetensi Inti (KI) dari kurikulum yang sedang berlaku. Materi yang dimuat dalam media pembelajaran berbasis android secara umum adalah Pengertian sistem imunitas, fungsi sistem pertahanan tubuh, antigen dan antibodi, mekanisme pertahanan, dan kelainan pada sistem Imunitas.

b. Design (Perancangan)

Tahap ini dilakukan dengan penentuan bentuk media yang akan dikembangkan, yaitu media pembelajaran berbasis android dengan aplikasi EdBiold. Persiapan dan perancangan media pembelajaran berbasis android ini dilakukan dengan menyusun materi Sistem Imunitas menggunakan Microsoft Word 2013 dengan format file .docx, kemudian materi dibuat ke dalam bentuk format $\mathrm{html}$ aplikasi dengan menggunakan Android Studio versi 4.0 secara offline, untuk dibuat ke dalam format file .apk dengan dimasukkan ke dalam Google Play atau PlayStore sehingga dapat diunduh dan diinstall ke dalam smartphone dengan berbagai macam versi android, dimulai dari versi 4.0 (jelly bean) dan seterusnya ke atas.

c. Development (Pengembangan)

Langkah pertama pada tahapan pengembangan yaitu proses validasi oleh empat validator yaitu satu dosen ahli materi, satu dosen ahli media, dan dua guru mata pelajaran. Hasil uji validasi, media pembelajaran berbasis android pada materi sistem imunitas dinyatakan layak diuji coba dan digunakan dengan revisi.

Proses validasi dilakukan oleh para ahli, yaitu 2 orang dosen dan 2 orang Guru dengan mengisi lembar validasi. Berikut ini adalah hasil uji validasi yang disajikan pada table 4 dan 5 :

Tabel 4 Persentase hasil penilaian oleh para ahli media

\begin{tabular}{|c|c|c|}
\hline Aspek & Persentase & $\begin{array}{c}\text { Kriteria } \\
\text { Penilaian }\end{array}$ \\
\hline Desain Tampilan & $76,25 \%$ & Layak \\
\hline Aksesbilitas & $76,67 \%$ & Layak \\
\hline Penggunaan Bahasa & $83,34 \%$ & Sangat Layak \\
\hline Keterlaksanaa & $83,34 \%$ & Layak \\
\hline Rata-rata & $\mathbf{7 9 , 9 0 \%}$ & Layak \\
\hline
\end{tabular}

Tabel 5 persentase hasil penilaian oleh para ahli materi

\begin{tabular}{|c|c|c|}
\hline Aspek & Persentase & $\begin{array}{c}\text { Kriteria } \\
\text { Penilaian }\end{array}$ \\
\hline Kurikulum & $90,00 \%$ & Sangat Layak \\
\hline Penyajian Materi & $74,00 \%$ & Layak \\
\hline $\begin{array}{c}\text { Penggunaan } \\
\text { Bahasa }\end{array}$ & $80,00 \%$ & Layak \\
\hline Evaluasi & $83,34 \%$ & Sangat Layak \\
\hline Rata-rata & $\mathbf{8 1 , 8 4 \%}$ & Sangat Layak \\
\hline
\end{tabular}

Pengisian angket respon oleh siswa dilakukan dengan tujuan agar dapat diketahui tanggapan siswa terhadap penggunaan Media Pembelajaran Berbasis Android dengan Aplikasi EdBiold pada pembelajaran Sistem Imunitas. Adapun 
indikator respon tersebut ialah Desain tampilan, Aksesbilitas, Pemahaman materi, Latihan dan evaluasi keterlaksanaan Pengisian angket respon dilakukan oleh 15 siswa secara daring dengan hasil berikut ini yang disajikan pada Tabel 6:

Tabel 6 Persentase Respon Keseluruhan Peserta Didik Terhadap Media

Pembelajaran Tiap Aspek

\begin{tabular}{|c|c|c|c|}
\hline No & Aspek & Persentase & Kriteria \\
\hline 1 & Desain Tampilan & $84.50 \%$ & Sangat baik \\
\hline 2 & Aksesbilitas & $88.00 \%$ & Sangat baik \\
\hline 3 & $\begin{array}{c}\text { Pemahaman } \\
\text { Materi }\end{array}$ & $68.50 \%$ & Baik \\
\hline 4 & $\begin{array}{c}\text { Latihan dan } \\
\text { evaluasi }\end{array}$ & $71.00 \%$ & Baik \\
\hline 5 & Keterlaksanaan & $86.25 \%$ & Sangat Baik \\
\hline \multicolumn{2}{|c|}{ Rata-rata Tiap Aspek } & $\mathbf{7 9 . 6 5 \%}$ & Baik \\
\hline
\end{tabular}

Penilaian oleh ahli media dan ahli materi, mendapatkan rata-rata persentase $76.25 \%$, 76.67\%, dengan kriteria layak, pada aspek desain tampilan ini pada media yang dikembangkan tidak hanya menggunakan satu warna sehingga media terlihat lebih menarik, Menurut Prastowo (2018: 391) pengaturan posisi dan penggunaan warna yang mencolok dapat menarik perhatian siswa untuk melihat sehingga meningkatkan minat membaca dan belajar. Kemudian terhadap jenis font, tata letak materi dan gambar, jarak, dan tombol ikon dikatakan sudah terpenuhi dengan baik hal ini juga didukung oleh respon peserta didik terhadap aspek desain tampilan mendapatkan rata-rata persentase $84.50 \%$ dengan kriteria sangat baik. Pada aspek aksesbilitas juga didukung oleh respon peserta didik yang mana mendapatkan ratarata persentase $88.00 \%$ dengan kriteria sangat layak maka dapat disimpulkan media pembelajaran berbasis android ini berada pada kategori valid dan layak digunakan dari segi tampilan, dan aksesbilitas.

Selanjutnya pada aspek penggunaan Bahasa mendapatkan rata-rata persentase 83.34\% dari ahli media, $80.00 \%$ dari ahli materi dengan kategori sangat layak dan layak. Hal ini menunjukan bahwa materi pada media pembelajaran berbasis android disajikan dengan jelas dan dengan pemilihan bahasa yang tepat, sederhana, dan sesuai dengan tingkat perkembangan peserta didik. Sesuai dengan komponen sumber belajar menurut Prastowo (2018: 47-48) isi pesan atau materi harus sederhana, jelas, efektif dan mudah dipahami maknanya. Akbar (2013: 33) media pembelajaran harus disusun secara sederhana agar mudah digunakan. Selain itu, Purwanto (2012: 137) menyatakan bahwa kalimat sederhana adalah kalimat yang paling banyak disenangi dan dipahami orang.

Aspek keterlaksanaan mendapatkan rata-rata persentase $83.34 \%$ dengan kategori sangat layak, pengembangan media pembelajaran berbasis android ini bertujuan agar peserta didik dapat mengatur alur dan laju pembelajaran secara mandiri sehingga pembelajaran tidak terbatas pada jadwal pembelajaran di sekolah saja, dengan hasil aspek keterlaksanaan mendapatkan kriteria sangat layak maka media yang telah dikembangkan ini sudah sesuai dengan tujuan yang ada dikuatkan 
lagi dengan respon peserta didik pada aspek keterlaksanaan mendapatkan rata-rata persentase $86.25 \%$ dengan kriteria sangat baik.

Pernyataan tersebut sesuai dengan penelitian menurut Azizah (2018: 251) yang menyatakan bahwa kelebihan dari pembelajaran berbasis android ialah memberikan kesempatan pada peserta didik untuk mengontrol kecepatan laju belajarnya. Prastowo (2012: 25) juga menyatakan fungsi bahan ajar bagi peserta didik ialah membantunya belajar secara mandiri, belajar dimana saja dan kapan saja, dan membantunya belajar sesuai kecepatan serta urutan yang ia inginkan. Juga menurut Munir (2013: 113-114) yang menyatakan pembelajaran dengan bahan ajar interaktif akan melatih siswa untuk lebih mandiri dalam memperoleh ilmu pengetahuan serta lebih praktis dan terkendali.

Aspek kurikulum yang dinilai oleh ahli materi mendapatkan rata-rata persentase 90.00\% dengan kriteria sangat layak. Kelayakan kurikulum terdiri atas tiga indikator yaitu kesesuaian materi dengan kompetensi dasar, kesesuaian materi dengan indikator pencapaian kompetensi dan kesesuaian materi dengan tujuan pembelajaran pada materi sistem imunitas dikatakan dapat memenuhi dengan baik, hal ini sejalan dengan pernyataan Muljono (2007:14-23) bahwa fokus validasi adalah mengukur konstruk atau komponen kelayakan kurikulum yaitu keterkaitan isi buku teks pelajaran dengan KI, KD, IPK dan tujuan mata pelajaran.

Aspek selanjutnya yaitu aspek penyajian materi mendapatkan rata-rata persentase masing-masing $74.00 \%$ dan $83.34 \%$ dengan kriteria layak dan sangat layak maka dapat disimpulkan media pembelajaran berbasis android ini berada pada kategori valid dan layak digunakan dari segi penyajian materi dan sangat layak dari segi evaluasi. Hal ini didukung juga oleh respon peserta didik pada aspek pemahaman materi dan aspek latihan dan evaluasi masing-masing mendapatkan rata-rata persentase $68,50 \%, 71.00 \%$ dengan kriteria layak.

Berdasarkan Tabel 4 menunjukkan bahwa hasil penilaian dari ahli media, dan Tabel 5 hasil dari penilaian ahli materi, media pembelajaran berbasis android ini layak untuk digunakan. Dapat dilihat dari persentase rata-rata dari ahli media yang menunjukkan angka $79,90 \%$ yang mana mendapat kriteria layak dan dari ahli materi $81,84 \%$ yang mana mendapat kriteria sangat layak Sesuai dengan teori yang dikatakan Usman dan akbar (2008:71) pada rentang validitas 61\% - 80\% kualitas media layak dan dapat digunakan, pada rentang $81 \%-100 \%$ kualitas media sangat layak dan dapat digunakan tanpa revisi. Hal ini juga dijelaskan oleh Suharsimi Arikunto (2013:69), sebuah media pembelajaran dikatakan memiliki validitas jika hasilnya sesuai dengan kriterium, dalam arti memiliki kesejajaran antara hasil yang diperoleh dengan kriterium yang telah ditentukan.

Produk yang valid berarti produk tersebut layak untuk digunakan oleh peserta didik dan guru karena dapat membantu dalam proses pembelajaran. Sesuai yang dikemukakan oleh Haviz (2013:33) bahwa produk pembelajaran disimpulkan valid jika dikembangkan dengan teori yang memadai dan semua komponen produk pembelajaran antara satu dengan yang lainnya berhubungan secara konsisten. 
Data hasil perhitungan angket respon peserta didik secara keseluruhan menunjukkan hasil pada kriteria baik dengan angka persentase $79,65 \%$ dengan kriteria layak, hal ini sesuai dengan yang kemukakan Usman dan Akbar (2008:71) pada rentang validitas $61 \%$ - $80 \%$ kualitas media layak dan dapat digunakan, angket respon peserta didik ini terdiri lima aspek yaitu aspek desain tampilan terdiri dari dua indikator, aspek aksesbilitas terdiri dari dua indikator, aspek pemahaman materi terdari dari empat indikator, aspek latihan dan evaluasi terdari dua indikator, dan aspek keterlaksanaan terdiri dari dua indikator.

\section{SIMPULAN DAN SARAN}

\section{SIMPULAN}

Berikut ini adalah kesimpulan yang dapat diambil berdasarkan hasil penelitian dan pengembangan media pembelajaran berbasis android pada materi Sistem Imunitas :

1. Hasil uji validasi media pembelajaran berbasis android pada materi Sistem Imunitas oleh ahli media dan ahli materi memperoleh persentase sebesar $79,90 \%$ dengan kriteria valid dan layak dan $81,84 \%$ dengan kriteria valid dan sangat layak.

2. Respon siswa terhadap penggunaan media pembelajaran berbasis android pada materi Sistem Imunitas memperoleh hasil sebesar $79,65 \%$ dengan kriteria valid dan baik.

\section{SARAN}

Berdasarkan penelitian yang telah dilakukan, berikut adalah beberapa saran yang diharapkan dapat membantu dalam proses pengembangan media pembelajaran di waktu yang akan datang:

1. Dibutuhkan kemampuan dalam bidang teknologi atau kerja sama yang baik bersama ahli teknologi dalam mengembangkan sebuah media pembelajaran berbasis teknologi, sehingga akan memudahkan dan memaksimalkan proses pengembangan produk media pembelajaran.

2. Pengembangan media pembelajaran berbasis android dilakukan dalam waktu yang tidak sebentar, maka dibutuhkan perancangan dan persiapan yang matang agar menghasilkan produk media pembelajaran berbasis android yang lebih baik dan maksimal.

3. Perlu adanya peningkatan kesadaran dan kreativitas guru dalam aspek pengembangan media pembelajaran guna memfasilitasi kegiatan pembelajaran, sehingga keprofesionalitasan guru dapat meningkat serta memudahakan dalam proses pembelajaran guna mencapai tujuan pelajaran yang telah ditentukan.

\section{UCAPAN TERIMA KASIH}

Ucapan terimkasih kepada Dosen pembimbing I dan II yaitu Bapak Drs. Muhammad Muttaqien, M.Pd dan Bapak Hadiansah, M. Pd, serta guru dan sekolah yang dijadikan tempat penelitian yang telah membantu dalam penelitian ini.

\section{RUJUKAN}

Akbar, S. (2013). Instrumen Perangkat Pembelajaran. Bandung: PT Remaja Rosdakarya. 
Azizah, F. A. (2018). Pengembangan Mobile Learning Berbasis Aplikasi Android Mata Pelajaran Biologi pada Siswa Kelas XI. E-Journal Prodi Teknologi Pendidikan, 7 (3), 239-254.

Baharudin dan Esa Nur Wahyuni (2012). Teori Belajar dan Pembelajaran. Jogjakarta : Ar-Ruzz Media.

Cimer, A. (2012). What Makes Biology Learning Difficult andEffective : Student's Views. Educational Research and Reviews. Vol 7 (3) : 61-71.

Hackbarth. (1996). The Educational Technology Handbook. Englewood Cliffs: Educational Technology Publications.

M.Haviz. (2013). Research and Development; Penelitian di Bidang Kependidikan yang Inovatif, Produktif dan Bermakna. Jurnal Ta'dib Vol. 16, No. 1.

Irwanto. (2017). Penggunaan Smartphone Dalam Pembelajaran Kimia SMA. Holistik. Vol 2 (1).

Munir. (2017). Pembelajaran Digital. Bandung : Alfabeta.

Musfiqon.H.M. (2012). Pengembangan Media dan Sumber Pembelajaran. Jakarta: Prestasi Pustaka Publisher.

Nana Syaodih Sukmadinata. (2006). Metode Penelitian Pendidikan. Bandung: PT. Remaja Rosdakarya.

Nurwahyuningsih Ibrahim And Ishartiwi Ishartiwi. (2017). Pengembangan Media Pembelajaran Mobile Learning Berbasis Android Mata Pelajaran IPA Untuk Siswa SMP. REFLEKSI EDUKATIKA. Vol 8 (1).

Prastowo, A. (2018). Sumber Belajar \& Pusat Sumber Belajar Teori dan aplikasinya di Sekolah/ Madrasah. Depok: Prenadamedia Group.

Purwanto, M. N. (2012). Prinsip-prinsip dan Teknik Evaluasi Pengajaran. Bandung: PT Remaja Rosdakarya Offset.

Ratna Wilis Dahar. (2006) Dalam Gagne. Teori-teori Belajar dan Pembelajaran. Jakarta: Erlangga.

Riduwan. (2018). Dasar-dasar Statistika. Bandung: CV Alfabeta

Sugihartono dkk. (2007). Psikologi Pendidikan. Yogyakarta : UNY Press.

Sugito, Sukewi. (1994). Perencanaan Pembelajaran. Semarang: IKIP Semarang.

Sugiyono. (2013). Metode Penelitian Pendidikan, Pendekatan Kuantitatif, Kualitatif, dan $R \& D$. Bandung: Alfabeta.

Trianto. (2009). Mendesain Model Pembelajaran Inovatif-Progresif Prosedur. Jakarta: Kencana Prenada Media Group.

Usman , Moh Uzer. (2001). Menjadi Guru yang Profesional. Bandung: Rosda Karya. 